\title{
Survival of Inoculum of Phytophthora capsici in Soil Through Time Under Different Soil Treatments
}

\author{
Ronald D. French-Monar, Texas A\&M University, Department of Plant Pathology and Microbiology, TAMUS Ag- \\ ricultural Research and Extension Center, 6500 Amarillo Blvd. W, Amarillo 79106; Jeffrey B. Jones, University of \\ Florida-IFAS, Plant Pathology Department, Gainesville, FL 32611-0680; Monica Ozores-Hampton, University of \\ Florida-IFAS, Southwest Florida Research and Education Center, 2686 State Road 29 North, Immokalee, FL 34142- \\ 9515; and Pamela D. Roberts, University of Florida-IFAS, Plant Pathology Department, Southwest Florida Re- \\ search and Education Center, 2686 State Road 29 North, Immokalee, FL 34142-9515
}

\begin{abstract}
French-Monar, R. D., Jones, J. B., Ozores-Hampton, M., and Roberts, P. D. 2007. Survival of inoculum of Phytophthora capsici in soil through time under different soil treatments. Plant Dis. 91:593-598.

From September 2001 until August 2002 and from September 2002 until August 2003, inoculum of Phytophthora capsici consisting of mycelium and oospores was buried in soil under three different soil treatments: soil solarization, fumigation with methyl bromide and chloropicrin, and white-on-black plastic mulch without fumigation or solarization. The effect of these soil treatments on the population and survival of $P$. capsici was evaluated through time after 28, 63, 119, 175, 245, and 343 days. Three techniques were used for detection of the localized inoculum in soil: soil dilution plating (SDP), a modified soil dilution plating technique with an overlay assay to allow for extra incubation (mSDPO), and lemon leaf baiting of soil (LLB). No viable inoculum was detected from any soil samples from the fumigated plots regardless of the soil detection technique used. By the last sampling date, viable oospore inoculum was still detected in both soil solarization and nontreated soils, but only using mSDPO and LLB. Overall, the mSDPO assay was the most sensitive assay, followed by LLB. Using mSDPO, populations in the last sampling date were $32.9 \mathrm{CFU} / \mathrm{g}$ soil for the untreated plots and $14.7 \mathrm{CFU} / \mathrm{g}$ soil for the solarized plots. Survival of $P$. capsici for a year would indicate that oospores have the potential to survive from year to year, and possibly much longer, in Florida and other locations.
\end{abstract}

Phytophthora root and crown rot, caused by the oomycete Phytophthora capsici Leonian, is an important soilborne plant disease that causes economic losses in Florida on important fruit and vegetable crops such as bell pepper (Capsicum annuum L.), eggplant (Solanum melongena L. var. esculentum Nees), summer squash (Cucurbita pepo L.), tomato (Lycopersicon esculentum Mill.), and watermelon (Citrullus lanatus (Thunb.) Matsum. \& Nakai) $(32,35,37)$. This plant pathogen has a major economic impact on crop production in California, Florida, Illinois, Michigan, North Carolina, New Jersey, New Mexico, and worldwide $(16,21,22$, $38,46)$. South Florida has suffered major outbreaks in 1982, 1993, and 1998 (36,37). Since 1993, the incidence of $P$. capsici has increased in bell pepper and squash production fields throughout Florida $(32,36,40)$.

Corresponding author: P. D. Roberts

E-mail: pdr@ifas.ufl.edu

Accepted for publication 7 December 2006.

doi:10.1094/PDIS-91-5-0593

(C) 2007 The American Phytopathological Society
Many Phytophthora spp. do not survive extended periods away from their hosts, unlike fungal plant pathogens such as Fusarium oxysporum and the oomycete Pythium aphanidermatum (10). Mycelium, sporangia, and zoospores produced by most Phytophthora spp. survive only for a few weeks, chlamydospores may survive for up to 6 years, and oospores may last up to 4 years in nonsterile soil $(10,27)$. In $P$. capsici, there is no natural production of chlamydospores except for those isolates of tropical crops, which have been reclassified as $P$. tropicalis sp. nov. $(2,49)$. In 2005, Islam et al. (22) induced chlamydospore formation in liquid medium under laboratory conditions for nine of 24 isolates of $P$. capsici obtained from diseased pumpkin tissue in central Illinois.

Oospore survival in soil is assumed to be the main source of initial inoculum of $P$. capsici $(28,38)$. Bowers et al. (4) determined that $9 \%$ of oospores of $P$. capsici tested were or remained viable after 27 weeks in soil using a vital staining procedure. Viability may not translate to germination, and therefore, in the same study, this form of inoculum was only able to cause disease on pepper seedlings with inoculum as old as 16 weeks. In Brazil, Ansani and Matsuoka (1) determined that mycelium of $P$. capsici survived fewer than 120 days in infected hypocotyl and root tissue of pepper buried in the soil, while sporangia and zoospores survived in soil for fewer than 75 days.

In Florida, field production of vegetable crops is based on high-input, intensively managed production systems that utilize broad spectrum fumigants such as methyl bromide to manage soilborne pests $(5,8)$. Currently, one can only use methyl bromide from existing stocks and those allowed by critical use exemptions (CUE). For 2007, CUEs have been approved for crops such as pepper, tomato, eggplant, and strawberries (Kent Cushman, personal communication). Without a CUE from the phaseout of methyl bromide, the ban on this fumigant could have potentially cost Florida fresh fruit and vegetable growers over $\$ 636$ million in lost revenue (43). Much of the loss is attributed to decreased acreage and production that would arise in the absence of methyl bromide as a soil fumigant. Tomato acreage in Florida is expected to decrease by $50 \%$ and overall production by more than $60 \%$ (43). Chemical alternatives such as the combination of fumigants Telone (1,3-dichloropropene) + chloropicrin with the herbicide Tillam (pebulate) are more expensive and may also be subject to future restrictions.

Nonchemical alternatives such as solarization are as yet largely unproven but do offer promise of sustainable solutions. Solarization with clear plastic and UVabsorbing clear plastic can raise soil temperatures to $45^{\circ} \mathrm{C}$ or higher, allowing for reduced weed emergence after solarization is terminated $(19,20)$. Soil moisture increases soil heat conductivity and sensitizes seeds to high temperatures. Clear plastic mulch decreased pigweed (Amaranthus retroflexus L.) populations within 2 weeks to less than $10 \%$ for 1 year, demonstrating the sensitivity of some annual weeds to solarization (20).

McGovern et al. (31) reported a reduction of Phytophthora blight of Madagascar periwinkle (Catharanthus roseus (L.) G. Don) in three separate years with soil solarization in autumn. Soil solarization suppressed the development and final incidence of Phytophthora blight in periwinkle 
but did not eliminate the pathogen. Barbercheck and Von Broembsen (3) determined that solarization for 3 weeks eliminated P. cinnamomi from $91 \%$ of buried infested wheat grains and completely eradicated the pathogen after 6 weeks.

The ability of a fungal plant pathogen to persist in soil depends on its efficiency for survival in soil or in diseased host tissue buried in soil, sensitivity to temperature and temperature fluctuations, soil moisture, and microbial activity. The depth at which inoculum of $P$. capsici was buried in soil was not a significant determinant for survival and detection of $P$. capsici $(1,4)$. Viability and colony counts were not significantly different whether oospores were buried 5 or $20 \mathrm{~cm}$ deep (4).

The failure to detect $P$. capsici in soil does not mean that the pathogen is no longer present. According to Mitchell and Kannwischer-Mitchell (34), in areas where Phytophthora species are endemic, initial inoculum, most likely in the form of chlamydospores or oospores, is often not detected. Low or undetectable levels of inoculum have been observed to increase to high concentrations when environmental conditions favor population growth (34).

Sampling techniques for detection of propagules of $P$. capsici may include soil dilution plating, baiting soil with pepper leaf disks, and soil saturation followed by dilution plating (29). In studies by McGovern et al. (31) on the effect of soil solarization on $P$. nicotianae propagule densities, soil dilution plating failed to detect the pathogen in 2 out of 3 years of study. However, incidence of Phytophthora blight on Madagascar periwinkle in the field was as high as $14.8 \%$ for 1 year. No single technique is suitable for all types of inoculum since each technique may be more sensitive to a specific propagule type (38).

The objective of this study was to evaluate the effects of soil solarization and fumigation with methyl bromide-chloropicrin on the survival of $P$. capsici in south Florida soils. Assessment of how long inoculum may survive in soil was used as the indicator for potential of initial inoculum to survive from year to year.

\section{MATERIALS AND METHODS}

Field site. The field experiments were conducted from September 2001 until August 2002 and from September 2002 until August 2003 at the University of Florida's Southwest Florida Research and Education Center in Immokalee, FL. The same site was chosen for both years of study and did not have a recent history of $P$. capsici. The soil was Immokalee fine sand (sandy, siliceous, hyperthermic Arenic Haplaquods). Immokalee fine sand is typically $97 \%$ sand, $2.5 \%$ silt, $0.3 \%$ clay, with an organic matter content of $1.96 \%$ and $\mathrm{pH} 4.2$ at a depth of 0 to $13 \mathrm{~cm}$ $(40,41,42)$. The top $15 \mathrm{~cm}$ of soil was typi- cally dark gray, a combination of organic matter and lightly gray sand. The next 15 $\mathrm{cm}$ of soil consisted of loose, gray, fine sand. Three soil treatments were arranged in a randomized complete block design and were replicated six times. Treatments were (i) soil solarization, (ii) soil fumigated with methyl bromide-chloropicrin 67:33, and (iii) nontreated soil. Using soil dilution plating and pepper seedling bioassays, the soil was tested and found not to contain propagules of $P$. capsici or any other species of Phytophthora (data not shown).

Inoculum production. Two isolates of P. capsici, Cp30 (A1 compatibility type) and $\mathrm{Cp} 32$ (A2 compatibility type), were isolated from bell pepper (Capsicum annuum L.) in 1997 and 1998, respectively, and used for oospore production in this study. Isolates were provided by the Phytophthora Collection, Plant Pathology Department, University of Florida, Gainesville. Both isolates were maintained on BBL (Becton, Dickinson and Company, Sparks, MD) cornmeal agar (CMA).

Approximately $25 \mathrm{~g}$ of hard red winter wheat (Triticum aestivum L.) seeds were added to a $250-\mathrm{ml}$ flask containing $25 \mathrm{ml}$ of deionized water (34). Seeds were soaked for $24 \mathrm{~h}$ and autoclaved twice for $20 \mathrm{~min}$ on two consecutive days. Each flask was inoculated with five 5-mm disks from a 4-day-old culture of each isolate, $\mathrm{Cp} 30$ and $\mathrm{Cp} 32$, which were grown separately on $10 \%$ V8 juice agar (33). Cultures were incubated for 21 days at $25^{\circ} \mathrm{C}$ in the dark and shaken every 3 days to prevent clumping.

Field experiments. Infested seeds were shredded to about 1- to 2-mm-diameter pieces using a Black \& Decker (Black \& Decker Corporation, Towson, MD) Handy Chopper Plus HC 3000 mincer/chopper and added to microwaved Immokalee fine sand soil by mixing $20 \mathrm{~g}$ of shredded seeds per kilogram of soil. One kilogram of soil was microwaved in a Sharp (Sharp Electronics Corporation, Mahwah, NJ) R9H84B 900-watt microwave for $5 \mathrm{~min}$. Approximately $12 \mathrm{~g}$ of infested soil was added to $5 \times 5 \mathrm{~cm}$ envelopes made from Versapor 3000 (Pall Corporation, Ann Arbor, MI) acrylic membranes with 3- $\mathrm{mm}$ pore size (9). Envelopes were sealed with 3M Scotch 600 transparent adhesive tape and kept in the laboratory at $24^{\circ} \mathrm{C}$ under moist conditions. Within $18 \mathrm{~h}$, envelopes containing infested soil were buried in soil at a depth of $15 \mathrm{~cm}$ prior to treatments of solarization or methyl bromide treatments. One envelope for each of six replicates per treatment were randomly sampled after 28 , $63,119,175,245$, and 343 days and assayed for $P$. capsici, for a total of six envelopes per treatment.

Soil solarization was performed on raised beds that were formed in the fall of each year. Solarization began 14 September 2001 and 5 September 2002, and con- tinued for 28 days, using clear highdensity $19-\mu \mathrm{m}$ gas-impermeable polyethylene film containing UV light inhibitors (Sonoco Products Co., Orlando, FL). Solarization treatment was stopped after 28 days by applying a $30-\mu \mathrm{m}$-thick, white-onblack, low-density polyethylene film (Edison Plastics, Lee Hall, VA) over the solarization film. Soil fumigation treatments with methyl bromide and chloropicrin (67:33) were applied on the same dates that soil solarization was initiated. Methyl bromide and chloropicrin were applied at the rate of $392 \mathrm{~kg} / \mathrm{ha}$, and beds were covered with the white-on-black film.

Bell pepper cultivar "Enterprise" (Seminis, Inc., Oxnard, CA) plants were transplanted after soil treatment termination on 18 October 2001 and 8 October 2002. Plants were transplanted into raised beds $0.81 \mathrm{~m}$ wide, $0.20 \mathrm{~m}$ high, with $1.80 \mathrm{~m}$ between centers. Pepper plant spacing was $25 \mathrm{~cm}$ between plants and in double rows separated by $45 \mathrm{~cm}$, giving a plant population of 43,243 plants/ha. Peppers were planted to replicate grower conditions and to monitor for the presence of $P$. capsici during the growing season. Plants were irrigated by drip irrigation, and the tubing was a $0.25-\mathrm{mm}$ biwall type with flow rates of $3.65 \mathrm{~m}^{3}$ per day positioned in the center of the bed prior to the mulch application. Emission points were located on $30-\mathrm{cm}$ spacing. Drip irrigation duration was $1 \mathrm{~h}$, twice per day. Irrigation amounts were based on tensiometer readings to maintain soil-water potential greater than $-15 \mathrm{kPa}$, which is equivalent to approximately $8 \%$ soil moisture. Tensiometers were located in the plant row at 30 and $60 \mathrm{~cm}$ depths and monitored twice per week. Soil sanitation treatments were $10 \mathrm{~m}$ long, with $2 \mathrm{~m}$ on each side with no plantings. Envelopes were buried in this nonplanted area. Each replicate had at least six envelopes buried at the end of each treatment replicate, and half the envelopes were buried on each of the two ends of the treatment replicates.

To measure soil temperature during solarization, thermocouple soil temperature sensors were used to collect data from the soil surface and depths of 5, 10, 15, and 20 $\mathrm{cm}$. The temperature sensors were connected to a compact modular CR10X datalogger (Campbell Scientific, Inc., Logan, UT). The datalogger collected hourly average temperatures, and data were downloaded once every week. Data were processed as accumulated number of hours over $40,45,50$, and $55^{\circ} \mathrm{C}$.

Standard soil dilution plating assay for detection of inoculum. Four grams of soil from each envelope were added to 16 $\mathrm{ml}$ of $0.25 \%$ sterile water agar and stirred for $2 \mathrm{~min}$; 1-ml samples were then plated on PARPH medium, for a 1:5 soil dilution plating (SDP) (29). This medium consists of $17 \mathrm{~g}$ of CMA in 1 liter of deionized water amended with $5 \mathrm{mg}$ of pimaricin, $250 \mathrm{mg}$ of ampicillin, $10 \mathrm{mg}$ of rifampicin, 
$100 \mathrm{mg}$ of pentachloronitrobenzene (PCNB), and $50 \mathrm{mg}$ of hymexazol per liter of medium (23). A total of 10 PARPH plates were used for each soil sample. Plates were incubated in the dark at $24^{\circ} \mathrm{C}$ for $96 \mathrm{~h}$, and then rinsed under running water to remove the soil from the surface of the medium. Suspect colonies of $P$. capsici were circled on the bottom of the petri plate with a permanent marker to delineate colony growth and counted. Two random colonies per sampling period for each treatment were cleaned through a Van Tieghem (VT) cell in PARPH medium for species confirmation (10). A VT cell, in this case a glass or rubber ring of $0.5 \mathrm{~cm}$ length placed in the agar medium right after pouring the agar, forces the mycelium to grow under and laterally through the cell to free the mycelium from bacteria. Isolates were then stored on CMA.

Modified soil dilution plating assay for detection of inoculum. For the modified soil dilution plating-agar overlay method (mSDPO), a 15-ml second layer of agar consisting of $10 \%$ clarified V8 juice agar, amended with the same chemicals as in PARPH medium, was poured over the SDP plates after the first colony reading or observation (13). The mSDPO plates were incubated in the dark for an additional $72 \mathrm{~h}$ at $24^{\circ} \mathrm{C}$. Plates were examined for new colony growth, and mycelia was observed under the microscope at $\times 40$ and $\times 100$ magnification for the presence of sporangia and mycelia characteristic of $P$. capsici. For 2002-2003, colony counts were facilitated by gently poking through the middle of the overlay, cracking the agar overlay, and sliding it off the plate while leaving the original SDP layer intact. Suspect colonies of $P$. capsici were circled on the bottom of the petri plate with a permanent marker to delineate colony growth and counted. Two random colonies per sampling period for each treatment were cleaned through a Van Tieghem cell in PARPH medium for species confirmation (10).

Leaf baiting of soil for detection of inoculum. A modified baiting technique using lemon (Citrus jambhiri Lush.) leaves was utilized for soil samples collected 119, 175,245 , and 343 days after burial in soil. This lemon leaf baiting (LLB) technique was used because detection of viable propagules by SDP previously was shown to decline or was undetectable in soil 12 weeks after soil infestation (4). The perimeter of the rough lemon leaves was cut with scissors, and at least seven cuts per side were made at a $45^{\circ}$ angle toward the midvein $(15,41,48)$. For each sample, a total of $4 \mathrm{~g}$ of soil was added to a $355-\mathrm{ml}$ foam bowl (12). Approximately $100 \mathrm{ml}$ of sterile deionized water amended with pimaricin, ampicillin, rifampicin, $\mathrm{PCNB}$, and hymexazol at the same concentrations as in PARPH medium was added to each bowl. One precut rough lemon leaf was gently floated on the surface of the water in each bowl.

Bowls were covered with black plastic and kept in the dark at $24^{\circ} \mathrm{C}$ for 5 days; leaves were then rinsed with sterile deionized water, blotted dry, and five leaf sections of approximately $1 \mathrm{~cm}^{2}$ each were plated onto each of two plates of PARPH medium for a total of 10 leaf sections per sample (24). PARPH plates were incubated in the dark at $24^{\circ} \mathrm{C}$ and observed after $72 \mathrm{~h}$ for colony growth. Colony observations and readings were continued every $24 \mathrm{~h}$ for up to 5 days. Two suspect mycelial growths emanating from the leaf sections for each treatment were transferred to a fresh PARPH plate containing a VT cell for clean up, observation, and species confirmation (10).

Pathogen confirmation. Species confirmation was based on morphological characteristics and sporangial morphometrics $(10,44,45)$. During the last successful sampling date for each treatment, two colonies were further validated as $P$. capsici by using polymerase chain reaction (PCR) where DNA is amplified using the PCAP primer in combination with the universal primer ITS 1 (39). A DNA product of approximately $172 \mathrm{bp}$ is expected $(13,39)$.

Statistical analysis. Experiments were arranged in a randomized complete block design with six replications per soil treatment. Experiments were repeated once. Values from replicates were used for analysis of variance (ANOVA) using the Statistical Analysis System 9.0 for Windows (SAS Institute, Cary, NC). Means were separated by Fisher's protected least significant difference (LSD) at $P=0.05$ (14). Data were also subjected to repeated measures analysis using PROC GLIMMIX that uses SAS 9.1.3 release for determining the effects of technique and time (30).

\section{RESULTS}

Soil parameters. Temperatures were monitored for soil in the solarized beds. During soil solarization, the number of accumulated hours in temperature intervals over $40,45,50$, and $55^{\circ} \mathrm{C}$ decreased as depth increased in the soil profile (Table 1). At 4 P.M., in the solarized beds, the average soil temperatures per day at a 15$\mathrm{cm}$ depth were 36 and $35^{\circ} \mathrm{C}$ during 2001 and 2002, respectively (31). For the nontreated plastic mulch and fumigation plots, the highest temperature of soil at a $15-\mathrm{cm}$ depth was $24^{\circ} \mathrm{C}$ for both years at 4 P.M. These data were collected twice a week using a hand held digital thermometer. Soil moisture content in the soil inside the envelopes varied during sampling periods, but there was no significant variation between treatments during each sampling period (data not shown).

Effect of soil treatment, detection technique, and sampling time on recovery of $\boldsymbol{P}$. capsici through time. All envelopes that were retrieved still had good structural integrity and showed no signs of cracking or disintegration through time. No viable inoculum was detected from any soil samples from the methyl bromide fumigated plots at any sampling date in both years by the SDP, mSDPO, or LLB assay, this latter used during the last four sampling periods only. Viable inoculum was detected in both solarized and nontreated soil (Table 2).

The technique used to detect the presence and survival of $P$. capsici was a very important factor for both years of study where the significance levels $(P)$ were 0.03 or below (Table 3). However, time of sampling was not an important factor for either year and significance levels $(P)$ were 0.53 or above. Except for soil fumigation with methyl bromide, there was no difference among soil treatments in relationship to pathogen survival (data not shown).

Following solarization, at 28 days, soil samples were assayed and no $P$. capsici was detected in the solarized samples in 20012002. In 2002-2003, P. capsici was not detected using SDP but was detected in all six solarized sample replicates with the mSDPO assay. The nontreated soil samples had viable inoculum in both 2001-2002 and 2002-2003 as determined by both the SDP and $\mathrm{mSDPO}$ assays (Table 2).

After 119 days, SDP failed to detect viable inoculum in both years in the solarized samples, although mSDPO detected

Table 1. Cumulative hours within various temperature ranges at different soil depths in solarized beds during the fall 2001 and fall 2002 growing seasons

\begin{tabular}{lcrrrr}
\hline Depth (cm) & $\mathbf{4 0 - 4 5}^{\circ} \mathbf{C}$ & $\mathbf{4 5 - 5 0}^{\circ} \mathbf{C}$ & $\mathbf{5 0 - 5 5}^{\circ} \mathbf{C}$ & $\mathbf{> 5 5}^{\circ} \mathbf{C}$ & $\begin{array}{c}\text { Total hours } \\
\mathbf{> 4 0}^{\circ} \mathbf{C}\end{array}$ \\
\hline Cumulative hours, fall 2001 & & & & & \\
$\quad$ Surface & 202 & 153 & 92 & 44 & 491 \\
5 & 189 & 85 & 15 & 0 & 289 \\
10 & 139 & 31 & 0 & 0 & 170 \\
15 & 76 & 0 & 0 & 0 & 76 \\
20 & 19 & 0 & 0 & 0 & 19 \\
Cumulative hours, fall 2002 & & & & & 342 \\
Surface & 265 & 73 & 4 & 0 & 433 \\
5 & 330 & 103 & 0 & 0 & 263 \\
10 & 247 & 16 & 0 & 0 & 131 \\
15 & 131 & 0 & 0 & 0 & 22 \\
20 & 22 & 0 & 0 & 0 & \\
\hline
\end{tabular}


Table 2. Percentage of soil samples with viable inoculum of Phytophthora capsici as determined by soil dilution plating (SDP), modified soil dilution plating-overlay (mSDPO), and lemon leaf baiting (LLB) during six sampling periods per year of study

\begin{tabular}{|c|c|c|c|c|c|c|c|c|c|}
\hline \multirow[b]{3}{*}{ Year } & \multirow{3}{*}{$\begin{array}{c}\text { Days post } \\
\text { burial }\end{array}$} & \multicolumn{6}{|c|}{ Recovery of $P$. capsici $(\%)^{\mathrm{y}}$} & \multirow[b]{3}{*}{ LSD } & \multirow[b]{3}{*}{$P$ value } \\
\hline & & \multicolumn{3}{|c|}{ Soil solarization } & \multicolumn{3}{|c|}{ Nontreated } & & \\
\hline & & SDP & mSDPO & LLB & SDP & mSDPO & LLB & & \\
\hline \multirow[t]{6}{*}{$2001-2002$} & 28 & $0.0 \mathrm{c}$ & $0.0 \mathrm{c}$ & n.t. ${ }^{z}$ & $33.3 \mathrm{~b}$ & $100.0 \mathrm{a}$ & n.t. & 24.9 & $<0.0001$ \\
\hline & 63 & $0.0 \mathrm{~b}$ & $50.0 \mathrm{a}$ & n.t. & $83.3 \mathrm{a}$ & $83.3 \mathrm{a}$ & n.t. & 38.3 & $<0.0001$ \\
\hline & 119 & $0.0 \mathrm{c}$ & $100.0 \mathrm{a}$ & $100.0 \mathrm{a}$ & $50.0 \mathrm{~b}$ & $100.0 \mathrm{a}$ & $83.3 \mathrm{a}$ & 24.5 & $<0.0001$ \\
\hline & 175 & $16.7 \mathrm{~b}$ & $33.3 \mathrm{~b}$ & $100.0 \mathrm{a}$ & $33.3 \mathrm{~b}$ & $50.0 \mathrm{~b}$ & $100.0 \mathrm{a}$ & 38.8 & $<0.0001$ \\
\hline & 245 & $0.0 \mathrm{c}$ & $100.0 \mathrm{a}$ & $50.0 \mathrm{~b}$ & $0.0 \mathrm{c}$ & $100.0 \mathrm{a}$ & $83.3 \mathrm{a}$ & 26.5 & $<0.0001$ \\
\hline & 343 & $0.0 \mathrm{a}$ & $100.0 \mathrm{a}$ & $16.7 \mathrm{~b}$ & $0.0 \mathrm{~b}$ & $16.7 \mathrm{~b}$ & $16.7 \mathrm{~b}$ & 27.4 & $<0.0001$ \\
\hline \multirow[t]{6}{*}{$2002-2003$} & 28 & $0.0 \mathrm{~b}$ & $100.0 \mathrm{a}$ & n.t. & $100.0 \mathrm{a}$ & $100.0 \mathrm{a}$ & n.t. & 0.0 & $<0.0001$ \\
\hline & 63 & $0.0 \mathrm{~b}$ & $83.3 \mathrm{a}$ & n.t. & $0.0 \mathrm{~b}$ & $83.3 \mathrm{a}$ & n.t. & 27.8 & $<0.0001$ \\
\hline & 119 & $0.0 \mathrm{~d}$ & $83.3 \mathrm{ab}$ & $16.7 \mathrm{~cd}$ & $33.3 \mathrm{~cd}$ & $100.0 \mathrm{a}$ & $50.0 \mathrm{bc}$ & 36.8 & $<0.0001$ \\
\hline & 175 & $0.0 \mathrm{~d}$ & $100.0 \mathrm{a}$ & $33.3 \mathrm{c}$ & $0.0 \mathrm{~d}$ & $100.0 \mathrm{a}$ & $66.7 \mathrm{~b}$ & 28.3 & $<0.0001$ \\
\hline & 245 & $0.0 \mathrm{~b}$ & $100.0 \mathrm{a}$ & $83.3 \mathrm{a}$ & $16.7 \mathrm{~b}$ & $100.0 \mathrm{a}$ & $83.3 \mathrm{a}$ & 27.4 & $<0.0001$ \\
\hline & 343 & $0.0 \mathrm{c}$ & $100.0 \mathrm{a}$ & $33.3 \mathrm{~b}$ & $0.0 \mathrm{c}$ & $100.0 \mathrm{a}$ & $16.7 \mathrm{bc}$ & 25.5 & $<0.0001$ \\
\hline
\end{tabular}

y Means followed by the same letter within each row are not significantly different according to Fisher's LSD test $(P=0.05)$.

${ }^{\mathrm{z}}$ n.t. $=$ not tested.

Table 3. $F$ statistic and significance level $(P)$ for the test of the effect of technique or sampling time on detection of Phytophthora capsici

\begin{tabular}{llr}
\hline & \multicolumn{2}{c}{ Year } \\
\cline { 2 - 3 } Parameter & $\mathbf{2 0 0 1 - 2 0 0 2}$ & $\mathbf{2 0 0 2 - 2 0 0 3}$ \\
\hline Technique & $9.11(0.03)^{\mathrm{z}}$ & $11.35(0.02)$ \\
Time & $0.75(0.56)$ & $0.82(0.53)$ \\
\hline
\end{tabular}

${ }^{\mathrm{z}} F(P)$.

inoculum of $P$. capsici in 100 and $83 \%$ of the samples for 2001-2002 and 20022003, respectively. Compared to mSDPO, LLB varied in sensitivity and detected inoculum in 100 and $17 \%$ of solarized samples for 2001-2002 and 2002-2003, respectively. The nontreated soil samples contained viable inoculum in both years using all three techniques.

P. capsici was still recovered after 245 days from both the solarized and nontreated white plastic mulch samples using $\mathrm{mSDPO}$ and LLB; however, P. capsici was not detected in solarized soil using SDP in both years. The mSDPO assay detected $P$. capsici in all solarized and nontreated samples for both years, and LLB detected $P$. capsici in $83 \%$ of nontreated white plastic mulch soil samples for both years compared to 50 and $83 \%$ of solarized samples in 2001-2002 and 2002-2003, respectively (Table 2).

At the last sampling date, at 343 days, viable inoculum was still detected in both solarized and nontreated soils but only by using mSDPO and LLB (Table 2). For both years, all samples for the soil solarization treatments contained viable inoculum of P. capsici.

Population levels usually were significantly higher when using the mSDPO assay in comparison with the SDP (Table 4). Inoculum was not detected at all in both years with SDP in the solarized plots except 2001-2002 at 175 days when only $0.5 \mathrm{CFU} / \mathrm{g}$ of soil were assessed. The plastic mulch control soil assayed with SDP had populations that ranged from 0 to 38
CFU/g of soil in 2001-2002 and 0 to 33 CFU/g in 2002-2003.

Although LLB and mSDPO were able to equally determine that $P$. capsici was present in soil during all sampling periods when both techniques were used, mSDPO was more sensitive in $50 \%$ of the sampling periods for soil solarization for both years. The LLB assay was only more sensitive in $12.5 \%$ of sampling periods for both years of soil solarization. In the nontreated soil, $\mathrm{mSDPO}$ was more sensitive in $37.5 \%$ of samplings and only less sensitive than LLB in $12.5 \%$.

Validation of recovery of $\boldsymbol{P}$. capsici. Selected colonies for species confirmation were validated as $P$. capsici. These colonies were heterothallic, did not produce chlamydospores naturally, had semipapillate to papillate, caducous sporangia, and pedicels exceeded $35 \mu \mathrm{m}$ in length. Pairing with an opposite mating or compatibility type produced oospores that were mostly aplerotic and amphyginous in their antheridial attachment. Both compatibility types were found throughout the experiment (data not shown).

The use of the PCAP primer in a PCR reaction was successful in DNA amplification and yielding an estimated product of $172 \mathrm{bp}$, as expected for $P$. capsici. The PCR amplification validated the recovery of $P$. capsici in day 343 for soil solarization and the nontreated control for both mSDPO and LLB recovery techniques, for a total of eight positive matches.

Monitoring of Phytophthora blight in the field. Every 2 weeks, pepper plants located in each one of the six replicates per treatment were visually assessed for the presence of $P$. capsici. However, no pepper plantings showed symptoms associated with this pathogen. Any plant that was sick or moribund was checked for the presence of $P$. capsici by tissue plating on PARPH medium (13). In both years of the study, there was no diseased bell pepper plant sampled that tested positive for this oomycete.

\section{DISCUSSION}

This study determined that survival of localized inoculum of $P$. capsici in soil has the potential to survive for at least a year and possibly longer, as evidenced by the soil still containing as much as $33 \mathrm{CFU} / \mathrm{g}$ of soil. In the process, soil dilution plating (SDP) was found not to be the best technique for detecting whether inoculum had survived through time. For studies on survival, alternative techniques such as the modified soil dilution plating (mSDPO) assay and leaf baiting of soil proved more sensitive.

In this study, the first sampling from the solarization experiment did not contain any viable propagules in 2001-2002 using both SDP and mSDPO. In 2002-2003, mSDPO but not SDP detected viable inoculum in the samples. This would indicate that inoculum such as mycelium was controlled and oospores of $P$. capsici were reduced or injured by fall solarization. In the plastic mulch controls, viable inoculum was detected with both assays in both years. Lack of initial detection of inoculum in the solarized plots may be due to the initial raising of soil temperatures that may cause thermal death, membrane disruption, or inactivation of pathogenic microorganisms $(25,26)$. Phytophthora spp. are not as good saprophytes as Pythium or the eumycetes $(1,4,10)$. Solarized soil at a $15-\mathrm{cm}$ depth reached temperatures beyond $40^{\circ} \mathrm{C}$ during part of the solarization treatment, which could be enough to halt the growth of many isolates of $P$. capsici, which normally have optimum temperatures between 24 and $33^{\circ} \mathrm{C}(10,47)$. The failure to detect Phytophthora spp. following soil solarization may be attributed to both the SDP technique and delayed germination of propagules (11). No detection with SDP might explain why inoculum of Phytophthora spp. was not detected in other similar studies $(7,31)$. More time may have been required for growth or germination of a propagule, and that is what the $\mathrm{mSDPO}$ assay allowed for $(10,18)$. 
Table 4. Average number of colony forming units of Phytophthora capsici for each treatment per sampling period

\begin{tabular}{|c|c|c|c|c|c|c|c|}
\hline \multirow[b]{3}{*}{ Year } & \multirow{3}{*}{$\begin{array}{l}\text { Sampling time } \\
\quad \text { (in days) }\end{array}$} & \multicolumn{4}{|c|}{ Average number of CFU/g soil ${ }^{\mathrm{Z}}$} & \multirow[b]{3}{*}{ LSD } & \multirow[b]{3}{*}{$P$ value } \\
\hline & & \multicolumn{2}{|c|}{ Soil solarization } & \multicolumn{2}{|c|}{ Nontreated } & & \\
\hline & & SDP & mSDPO & SDP & mSDPO & & \\
\hline \multirow[t]{6}{*}{$2001-2002$} & 28 & $0.0 \mathrm{~b}$ & $0.0 \mathrm{~b}$ & $1.6 \mathrm{~b}$ & $6.6 \mathrm{a}$ & 2.5 & $<0.0001$ \\
\hline & 63 & $0.0 \mathrm{~b}$ & $1.4 \mathrm{~b}$ & $38.1 \mathrm{ab}$ & $60.0 \mathrm{a}$ & 56.4 & 0.1465 \\
\hline & 119 & $0.0 \mathrm{c}$ & $17.1 \mathrm{~b}$ & $2.4 \mathrm{c}$ & $34.7 \mathrm{a}$ & 13.3 & $<0.0001$ \\
\hline & 175 & $0.5 \mathrm{a}$ & $3.6 \mathrm{a}$ & $0.4 \mathrm{a}$ & $1.7 \mathrm{a}$ & 3.6 & 0.0312 \\
\hline & 245 & $0.0 \mathrm{c}$ & $29.1 \mathrm{~b}$ & $0.0 \mathrm{c}$ & $61.0 \mathrm{a}$ & 19.6 & $<0.0001$ \\
\hline & 343 & $0.0 \mathrm{~b}$ & $14.0 \mathrm{a}$ & $0.0 \mathrm{~b}$ & $1.7 \mathrm{~b}$ & 5.8 & $<0.0001$ \\
\hline \multirow[t]{6}{*}{$2002-2003$} & 28 & $0.0 \mathrm{c}$ & $86.6 \mathrm{~b}$ & $32.5 \mathrm{c}$ & $172.3 \mathrm{a}$ & 44.7 & $<0.0001$ \\
\hline & 63 & $0.0 \mathrm{~b}$ & $41.8 \mathrm{a}$ & $0.0 \mathrm{~b}$ & $70.6 \mathrm{a}$ & 34.8 & 0.0004 \\
\hline & 119 & $0.0 \mathrm{~b}$ & $15.0 \mathrm{~b}$ & $0.6 \mathrm{~b}$ & $158.7 \mathrm{a}$ & 58.0 & $<0.0001$ \\
\hline & 175 & $0.0 \mathrm{c}$ & $35.5 \mathrm{~b}$ & $0.0 \mathrm{c}$ & $108.6 \mathrm{a}$ & 32.8 & $<0.0001$ \\
\hline & 245 & $0.0 \mathrm{c}$ & $25.3 \mathrm{~b}$ & $0.2 \mathrm{c}$ & $82.5 \mathrm{a}$ & 12.3 & $<0.0001$ \\
\hline & 343 & $0.0 \mathrm{~b}$ & $14.7 \mathrm{~b}$ & $0.0 \mathrm{~b}$ & $32.9 \mathrm{a}$ & 14.7 & 0.0002 \\
\hline
\end{tabular}

y Soil was assayed using standard soil dilution plating (SDP) and a modified soil dilution plating-agar overlay (mSDPO) assay.

${ }^{\mathrm{z}}$ Means followed by the same letter within each row are not significantly different according to Fisher's LSD test $(P=0.05)$.

No pathogen was detected in 2001-2002 for sampling at 28 days, but it was found to be present on later dates. This could indicate that mycelium was no longer viable and that oospores were not mature enough or germination did not happen. Since propagules such as zoospores, mycelia, and sporangia are expected to survive fewer than 120 days, the last three samplings should have consisted of soil containing only viable oospores. Visual observations under the microscope revealed oospores as the source of origin of most colonies. These oospores were aplerotic and had germinated to form a colony, but in some instances, the initial mycelium had produced a terminal sporangium (18). Some colonies may have lost their oospores when soil dilution plates were washed to remove the soil overlay or were not easily observed under the microscope at $\times 40$ or $\times 100$ magnification.

Although occurring postsolarization, another mechanism responsible for decreasing inoculum levels in the solarized soil in this study may be biological control. Soil temperatures that were higher in the solarized plots at a $15-\mathrm{cm}$ depth may have promoted growth of microorganisms such as thermotolerant fungi, actinomycetes, and bacteria (17). These edaphic microorganisms may play an important role in reducing inoculum levels by competition, antibiosis, and parasitism or predation. Based on the results obtained only by SDP, fall soil solarization was effective at eradicating inoculum. Only once was inoculum detected by SDP and at a very low population of $0.5 \mathrm{CFU} / \mathrm{g}$ soil. However, the mSDPO may have allowed for delayed germination and colony formation during the extra 3 to 4 days of incubation. That could explain why colonies are not seen in the SDP plates and can later be counted once mSDPO allows for extra incubation time.

In the plastic mulch control, viable inoculum was detected in all 12 sampling dates with mSDPO but only seven times with SDP. After the 175-day sampling date and beyond, SDP determined population levels of $P$. capsici to be 0 to $0.6 \mathrm{CFU} / \mathrm{g}$ soil while $\mathrm{mSDPO}$ determined populations to be 1.7 to $108.6 \mathrm{CFU} / \mathrm{g}$ of soil. The fact that inoculum was not detected at all at 343 days with SDP but was detected with mSDPO could explain why inoculum is not detected in soil prior to the growing season: the technique used is not appropriate with low pathogen populations or if propagules require time to germinate $(29,34)$. In 2002-2003, high levels of inoculum were still detected after 343 days as the $\mathrm{mSDPO}$ assay estimated populations of $P$. capsici to be, on average, $32.9 \mathrm{CFU} / \mathrm{g}$ of soil.

If only the SDP technique had been used to assess the survival of $P$. capsici in soil under different soil treatments, solarization would have proven to be equally effective as methyl bromide in controlling pathogen populations in soil. However, due to the use of the other two detection techniques, $\mathrm{mSDPO}$ and LLB, it was determined that populations of this pathogen were still considerably present, although less prevalent than pathogen populations in the nontreated soil. Therefore, the use of more than one technique is very important to truly assess the occurrence of a pathogen in soil before or after a soil treatment is implemented.

The LLB technique was effective at determining that survival of $P$. capsici extended throughout all sampling periods. This type of baiting technique is a very simple procedure that has been commonly used for detection of Phytophthora spp. from soil or irrigation water $(15,41,48)$. The incubation period can be reduced, but for this experiment, 5 days took into account that oospores, sporangia, or encysted zoospores may require time to germinate. Germination of oospores may vary with type of soil treatment or age of the spore as has been previously reported in studies with oospores of $P$. capsici (18). The LLB, compared to soil dilution plating tech- niques, is a qualitative technique that does not estimate the population of a pathogen in soil. However it is useful if the sole purpose is to determine whether a pathogen is present. Soil dilution plating techniques require the use of 10 plates (for this study), and in some cases, only one of those plates had colony growth. If only one sampling time is used, all three techniques may prove important.

Inoculum of $P$. capsici in Florida survived in soil for at least 343 days, longer than in previous studies with the pathogen $(1,4)$. Inoculum was grown in wheat seeds, which may have protected $P$. capsici and increased its longevity. However, grinding the seeds to 1 to $2 \mathrm{~mm}$ in diameter allows for quick degradation in soil. Inoculum of $P$. capsici may survive in soil by infecting seeds or other plant tissue that may have come from a field crop or a weed (13). By using the mSDPO technique, survival was monitored and population counts determined when no colonies were detected with SDP. This long-term survival would reflect current assumptions that this pathogen may survive for many years $(16,28,38)$. Long-term studies on survival of propagules of $P$. capsici will allow for better disease management practices to be implemented in Florida and elsewhere.

\section{LITERATURE CITED}

1. Ansani, C. V., and Matsuoka, K. 1983. Sobrevivencia de Phytophthora capsici Leonian no solo (Survival of Phytophthora capsici Leonian in soil). Fitopatol. Bras. 8:269-276.

2. Aragaki, M., and Uchida, J. Y. 2001. Morphological distinctions between Phytophthora capsici and $P$. tropicalis sp. nov. Mycologia 93:137-145.

3. Barbercheck, M. E., and Von Broembsen, S. L. 1986. Effects of soil solarization on plantparasitic nematodes and Phytophthora cinnamomi in South Africa. Plant Dis. 70:945-950.

4. Bowers, J. H., Papavizas, G. C., and Johnston, S. A. 1990. Effect of soil temperature and soilwater matric potential on the survival of Phytophthora capsici in natural soil. Plant Dis. 74:771-777.

5. Cantliffe, D. J., Hochmuth, G. J., Locascio, S. J., Stansly, P. A., Vavrina, C. S., Polston, J. E., 
Schuster, D. J., Seal, D. R., Chellemi, D. O., and Olson, S. M. 1995. Production of solanaceae for fresh market under field conditions: Current problems and potential solutions. Acta Hortic. 412:229-244.

6. Chellemi, D. O., and Mirusso, J. 2006. Optimizing soil disinfestation procedures for fresh market tomato and pepper production. Plant Dis. 90:668-674.

7. Chellemi, D. O., Olson, S. M., and Mitchell, D. J. 1994. Effects of soil solarization and fumigation on survival of soilborne pathogens of tomato in northern Florida. Plant Dis. 78:11671172.

8. Chellemi, D. O., Olson, S. M., Mitchell, D. J., Secker, I., and McSorley, R. 1997. Adaptation of soil solarization to the integrated management of soilborne pests of tomato under humid conditions. Phytopathology 87:250-258.

9. Coelho, L. 1997. Reduction of populations of Phytophthora spp. with soil solarization under field conditions and thermal inactivation of Phytophthora nicotianae. Ph.D. diss. University of Florida, Gainesville.

10. Erwin, D. C., and Ribeiro, O. K. 1996. Phytophthora Diseases Worldwide. American Phytopathological Society, St. Paul, MN.

11. Freeman, S., and Katan, J. 1988. Weakening effect on propagules of Fusarium by sublethal heating. Phytopathology 78:1656-1661.

12. French-Monar, R. D., Jones, J. B., Hanlon, E. A., and Roberts, P. D. 2005. Soil monitoring of viable inoculum of Phytophthora capsici localized in soil under vegetable production conditions in Southwest Florida. Fitopatologia 41:178-187.

13. French-Monar, R. D., Jones, J. B., and Roberts, P. D. 2006. Characterization of Phytophthora capsici associated with roots of weeds on Florida vegetable farms. Plant Dis. 90:345-350.

14. Gomez, K. A., and Gomez, A. A. 1994. Statistical Procedures for Agricultural Research. 2nd ed. John Wiley \& Sons, New York.

15. Grimm, G. R., and Alexander, A. F. 1973. Citrus leaf pieces as traps for Phytophthora parasitica from soil slurries. Phytopathology 63:540-541.

16. Hausbeck, M. K., and Lamour, K. H. 2004. Phytophthora capsici on vegetable crops: Research progress and management challenges. Plant Dis. 88:1292-1303.

17. Hoitink, H. A. J., and Boehm, M. J. 1999. Biocontrol within the context of soil microbial communities: A substrate-dependent phenomenon. Annu. Rev. Phytopathol. 37:427446.

18. Hord, M. J., and Ristaino, J. B. 1991. Effects of physical and chemical factors on the germination of oospores of Phytophthora capsici in vitro. Phytopathology 81:1541-1546.

19. Horowitz, M. 1980. Weed research in Israel. Weed Sci. 28:457-460.

20. Horowitz, M., Regev, Y., and Herzlinger, G. 1983. Solarization for weed control. Weed Sci. 31:170-179.
21. Hwang, B. K., and Kim, C. H. 1995. Phytophthora blight of pepper and its control in Korea. Plant Dis. 79:221-227.

22. Islam, S. Z., Babadoost, M., Lambert, K. N., Ndeme, A., and Fouly, H. M. 2005. Characterization of Phytophthora capsici isolates from processing pumpkin in Illinois. Plant Dis. 89:191-197.

23. Jeffers, S. N., and Martin, S. B. 1986. Comparison of two media selective for Phytophthora and Pythium species. Plant Dis. 70:1038-1043.

24. Juarez-Palacios, C., Felix-Gastelum, R., Wakeman, R. J., Paplomatas, E. J., and DeVay, J. E. 1991. Thermal sensitivity of three species of Phytophthora and the effect of soil solarization on their survival. Plant Dis. 75:1160-1164.

25. Katan, J. 1981. Solar heating (solarization) of soil for control of soilborne pests. Annu. Rev. Phytopathol. 19:211-236.

26. Katan, J., and De Vay, J. E., eds. 1991. Soil Solarization. CRC Press, Boca Raton, Fl.

27. Krober, H. 1980. Uberdauerung einiger Phytophthora-Arten im Boden (Survival of some Phytophthora species in soil). Z. Pflanzenkr. Pflanzenschutz 87:227-235.

28. Lamour, K. H., and Hausbeck, M. K. 2000. Mefenoxam insensitivity and the sexual stage of Phytophthora capsici in Michigan cucurbit fields. Phytopathology 90:396-400.

29. Larkin, R. P., Ristaino, J. B., and Campbell, C. L. 1995. Detection and quantification of Phytophthora capsici in soil. Phytopathology 85:1057-1063.

30. Madden, L. V., Turechek, W. W., and Nita, M. 2002. Evaluation of generalized linear mixed models for analyzing disease data obtained in designed experiments. Plant Dis. 86:316-325.

31. McGovern, R. J., McSorley, R., and Urs, R. R. 2000. Reduction of Phytophthora blight of Madagascar periwinkle in Florida by soil solarization in autumn. Plant Dis. 84:185-191.

32. McGovern, R. J., Roberts, P. D., Kucharek, T. A., and Gilreath, P. R. 1998. Phytophthora capsici: New problems from an old enemy. Pages 9-16 in: 1998 Florida Tomato Institute Proceedings. University of Florida, Gainesville.

33. Miller, P. M. 1955. V-8 juice agar as a generalpurpose medium for fungi and bacteria. Phytopathology 45:461-462.

34. Mitchell, D. J., and Kannwischer-Mitchell, M. E. 1992. Phytophthora. Pages 31-38 in: Methods for Research on Soilborne Phytopathogenic Fungi. L. L. Singleton, J. D. Mihail, and C. M. Ruch, eds. American Phytopathological Society, St. Paul, MN

35. Parra, G., and Ristaino, J. B. 2001. Resistance to mefenoxam and metalaxyl among field isolates of Phytophthora capsici causing Phytophthora blight of bell pepper. Plant Dis. 85:1069-1075.

36. Ploetz, R. C., and Haynes, J. L. 2000. How does Phytophthora capsici survive in squash fields in southeastern Florida during the off-season? Proc. Fla. State Hortic. Soc. 113:211-215.
37. Ploetz, R., Heine, G., Haynes, J., and Watson, M. 2002. An investigation of biological attributes that may contribute to the importance of Phytophthora capsici as a vegetable pathogen in Florida. Ann. Appl. Biol. 140:61-67.

38. Ristaino, J. B., and Johnston, S. A. 1999. Ecologically based approaches to management of Phytophthora blight on bell pepper. Plant Dis. 83:1080-1088.

39. Ristaino, J. B., Madritch, M., Trout, C. L., and Parra, G. 1998. PCR amplification of ribosomal DNA for species identification in the plant pathogen genus Phytophthora. Appl. Environ. Microbiol. 64:948-954.

40. Roberts, P. D., McGovern, R. J., Hert, A., Vavrina, C. S., and Urs, R. R. 1999. Phytophthora capsici on tomato: Survival, severity, age, variety, and insensitivity to mefenoxam. Pages 41-43 in: Florida Tomato Institute Proceedings. C. S. Vavrina, ed. University of Florida and Citrus \& Vegetable Magazine PRO 516

41. Roberts, P. D., Urs, R. R., French-Monar, R. D., Hoffine, M. S., Seijo, T. E., and McGovern, R. J. 2005. Survival and recovery of Phytophthora capsici and oomycetes in tailwate and soil from vegetable fields in Florida. Ann. Appl. Biol. 146:351-359.

42. Soil Conservation Service. 1999. Soil Survey of Hendry County, Florida. Florida: USDA Soil Conservation Service, University of Florida, IFAS

43. Spreen, T. H., VanSickle, J. J., Moseley, A. E., Deepak, M. S., and Mathers, L. 1995. Use of methyl bromide and the economic impact of its proposed ban on the Florida fresh fruit and vegetable industry. Univ. Fla. Tech. Bull. 898.

44. Stamps, D. J. 1985. Phytophthora capsici. Commonw. Mycol. Inst. Descriptions of Pathogenic Fungi and Bacteria. No. 835

45. Stamps, D. J., Waterhouse, G. M., Newhook, F. J., and Hall, G. S. 1990. Revised tabular key to the species of Phytophthora. Mycological Papers, no. 162. Commonwealth Agricultural Bureau, International Mycological Institute, Kew, England.

46. Tamietti, G., and Valentino, D. 2001. Physiological characterisation of a population of Phy tophthora capsici Leon. from northern Italy. J. Plant Pathol. 83:199-205.

47. Tsao, P. H. 1991. The identities, nomenclature and taxonomy of Phytophthora isolates from black pepper. Pages 185-211 in: Diseases of black pepper. Y. R. Sarma and Premkumar, eds. Proc. Int. Pepper Comm. Workshop Black Pepper Dis. Goa, India.

48. Von Broembsen, S. L. 1999. Disease management for nurseries using recycling irrigation systems. Oklahoma Cooperative Extension Service, Oklahoma State University. Online publication.

49. Zhang, Z. G., Zhang, J. Y., Zheng, X. B., Yang, Y. W., and Ko, W. H. 2004. Molecular distinctions between Phytophthora capsici and $P h$. tropicalis based on ITS sequences of ribosomal DNA. J. Phytopathol. 152:358-364. 